\title{
Growth and bioerosion of three massive corals on the Belize barrier reef
}

\author{
Raymond C. Highsmith ${ }^{1}$, Rebekka L. Lueptow and Sandra C. Schonberg \\ Department of Zoology, University of Washington, Seattle, Washington 98195, USA
}

\begin{abstract}
X-radiographic techniques were used to measure growth rates and bioerosional damage in 3 massive coral species collected at Carrie Bow Cay, Belize. Montastrea annularis grew significantly faster $\left(\overline{\mathrm{x}}=6.34 \mathrm{~mm} \mathrm{yI}^{-1}\right)$ than Porites astreoides $\left(\overline{\mathrm{x}}=4.75 \mathrm{~mm} \mathrm{yr}^{-1}\right)$ and both grew significantly faster than $M$. cavernosa $\left(\overline{\mathrm{x}}=4.36 \mathrm{~mm} \mathrm{yr}^{-1}\right)$. $M$. annularis (when combined with data from Weber and White, 1977 ) and $M$. cavernosa growth rates were inversely correlated with water depth. $M$. annularis skeletons were significantly more excavated $(\bar{x}=7.9 \%$ of cross-sectional area) than $M$. cavernosa $(\overline{\mathrm{x}}=5.3 \%)$ or $P$. astreoides $(\overrightarrow{\mathrm{x}}=4.8 \%)$ skeletons. Over $80 \%$ of skeletal excavation occurred within $2 \mathrm{~cm}$ of a dead surface in all 3 species. Bioerosion within this 'dead area' was significantly greater in $M$. annularis $(\overline{\mathrm{x}}=15.3 \%$ of cross-sectional area) than in $M$. cavernosa $(\overline{\mathrm{x}}=12.1 \%)$ or $P$. astreoides $(\overline{\mathrm{x}}=8.0 \%)$, and significantly greater in $M$. cavernosa than in P. astreoides. Boring sponges accounted for 85 to $94 \%$ of skeletal excavation, with polychaetes, bivalves, and sipunculans accounting for the balance. Differences in percentage excavation correspond to differences in skeletal density (dense species are more bored), proportion of dead skeletal surface available for recruitment by boring organisms (although anomalous results were obtained for $P$. astreoides because of an encrusting sponge associate), and possibly to differences in plankton primary productivity
\end{abstract}

\section{INTRODUCTION}

Rate of expansion of coral reefs depends on rates of skeletogenesis of their constituent frame-builders and their resistance to physical, chemical and biological destructive processes (Goreau, 1959; Hein and Risk, 1975; MacGeachy and Stearn, 1976). In this regard, bioerosion of coral skeletons is an important but littlestudied process on coral reefs. In addition to measurement of growth rates (Knutson et al., 1972), x-radiographs of coral skeletal sections have been used recently to measure the amount of calcium carbonate removed by burrowing organisms (Hein and Risk, 1975; MacGeachy and Stearn, 1976; MacGeachy, 1977; Highsmith, 1981a). Both MacGeachy (1977) at Barbados and Highsmith (1981a) at Enewetak found differences in bioerosional damage between species and related these differences to differences in the biology of the corals. In addition to their relevance to reef development, coral growth rates, as revealed by $\mathrm{x}$ radiography, are potentially useful environmental

\footnotetext{
1 Present address: Seward Marine Center, Institute of Marine Science, University of Alaska, Seward, Alaska 99664, USA
}

indicators (Hudson et al., 1976; Dodge, 1978), and also provide insights into the calcifying mechanism (Highsmith, 1979).

We present data here for 3 of the most common massive coral species on Caribbean reefs: Montastrea annularis (Ellis and Solander), M. cavernosa (Linnaeus), and Porites astreoides (Lamarck). In addition to providing added information on differential growth and excavation of coral species, these data are also of interest because, with the exception of a limited investigation in the Florida inner reef tract (Hein and Risk, 1975), previous studies have been on oceanic islands rather than coastal reefs subject to continental influences such as heavy run-off.

\section{METHODS}

This study was conducted at the Smithsonian Institution's IMSWE Laboratory, Carrie Bow Cay, Belize $\left(\sim 17^{\circ} \mathrm{N}: 88^{\circ} \mathrm{W}\right)$. Montastrea annularis, $M$. cavernosa, and Porites astreoides were collected at several locations on the barrier reef (fore-reef slope, inner reef slope, upper spur and groove zone, reef crest, and 
patch reef zone; see Fig. 1 in Highsmith et al., 1980) and at patch reefs approximately $1.5 \mathrm{~km}(\sim 7 \mathrm{~m}$ depth) and $5 \mathrm{~km}(\sim 2 \mathrm{~m}$ depth; Blue Ground Range) behind the reef crest (see Fig. 2 in Rützler and Macintyre, 1982).

The volume of each head was estimated by water displacement. In addition, the maximum circumference perpendicular to the plane of maximum upward growth, live-tissue margin circumference, and basalattachment circumference were measured. When the live-tissue margin varied up and down, the measurement was made at the approximate midpoint.

A slab through the major growth axis was cut from each coral head. Care was taken to ensure that the slabs of each species were of uniform thickness, the width being 1 to 3 times calice diameter (Buddemeier et al., 1974). The slabs were $x$-rayed using a Faxitron Model 8060-63 x-ray unit at 65 KVP and Kodak No. 156-0706 XR-2 film. Alternating high and low density bands in the skeleton are revealed on the $x$-radiographs (Fig. 1), one band pair representing one year's growth (Knutson et al., 1972; Hudson et al., 1976). Mean linear growth rate for each head was calculated by counting band pairs along the major vertical growth axis, then measuring the distance between the first and last pairs. For Montastrea annularis, growth in mass was calculated using a mean skeletal bulk density of $1.75 \mathrm{~g} \mathrm{~cm}^{-3}$ (Dustan, 1975). We estimated bulk densities for $M$. cavernosa and Porites astreoides by the mercury displacement method (Dustan, 1975) using 5 replicate measurements on each of 3 cubes per head cut from selected heads.

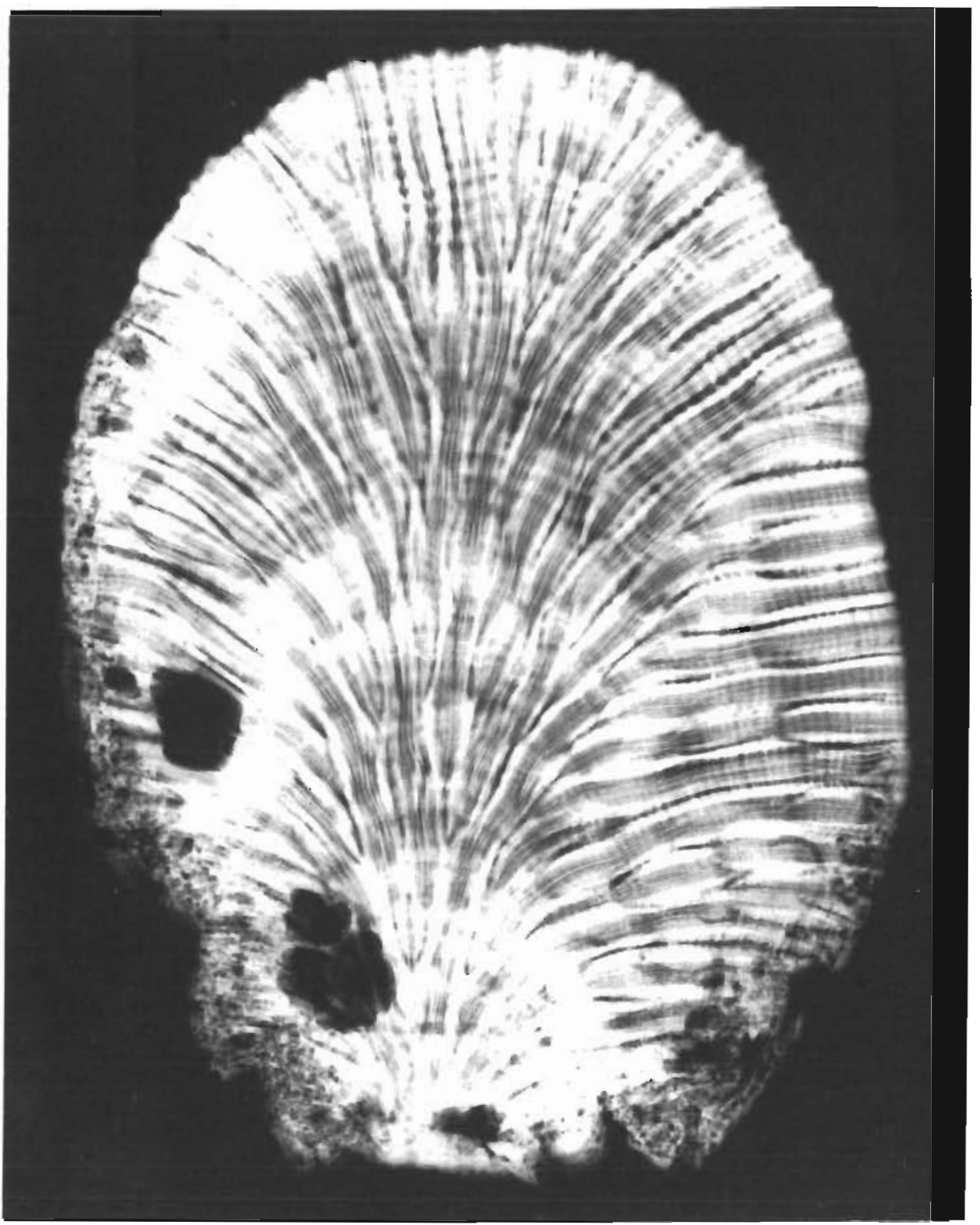

Fig. 1. Montastrea cavernosa. $\mathrm{X}$-radiograph of a slab showing alternating high density (light) and low density (dark) bands. A high-density and low-density band couplet is produced each year. The large cavities were made by the boring sponge Siphonodictyon 
The $x$-ray negatives also show the extent and characteristic pattern of skeletal excavation by various boring organisms (Hein and Risk, 1975; MacGeachy and Stearn, 1976; MacGeachy, 1977; Highsmith, 1981a), making it possible to assess the relative importance of different groups of borers. The percentage of area bored in each coral head was estimated by placing the $\mathrm{x}$-radiograph on a light table and overlaying it with an acetate sheet marked with a grid of $0.25 \mathrm{~cm}^{2}$ squares. Areas were measured using an electric planimeter or, for small areas, estimated by counting squares on the grid. Because Highsmith (1981a) found that most bioerosional damage occurs within $2 \mathrm{~cm}$ of dead surface areas in Enewetak corals, skeletal excavation within $2 \mathrm{~cm}$ of a dead surface (referred to as dead area') was also recorded. This measurement is of interest because, in general, dead surfaces occur on the basal region of corals (Highsmith, 1981a). Thus, a concentration of burrows in the 'dead area' has a greater weakening effect on the coral's attachment to the substratum than would be the case if burrows were distributed more evenly throughout the head.

\section{RESULTS}

\section{Growth rates}

Montastrea annularis grew significantly faster than both Montastrea cavernosa $(\mathrm{P}<.001)$ and Porites astreoides $(\mathrm{P}<.004)$; the latter also grew faster than $M$. cavernosa $(\mathrm{P}<.05$, Mann-Whitney U-tests; Table 1). Growth rates for $M$. cavernosa decreased significantly with increasing depth $\left(\mathrm{P}<.05, \mathrm{I}_{\mathrm{s}}=-0.55\right.$; Fig. 2) but those for $M$. annularis and $P$. astreoides did not $\left(\mathrm{r}_{\mathrm{s}}=-.29\right.$ and +.05 , respectively; Spearman rank tests). However, if the $M$. annularis growth rates are

Table 1. Mean growth rates of 3 massive corals from Belize expressed as $\mathrm{mm} \mathrm{yr}^{-1}$ (linear) and $\mathrm{g} \mathrm{cm}^{-2} \mathrm{yr}^{-1}$ (mass): 1 to 3 sets of measurements were made per head; $N=$ no. of heads. See Table 2, Row 13 for mean skeletal densities used to calculate growth in mass

\begin{tabular}{|c|c|c|c|c|}
\hline Coral & Mean & Range & $\mathrm{N}$ & $\begin{array}{c}\text { Depth } \\
\operatorname{span}(m)\end{array}$ \\
\hline \multicolumn{5}{|c|}{ Montastrea annularis } \\
\hline Linear & 6.34 & $3.7-9.8$ & \multirow[t]{2}{*}{19} & \multirow[t]{2}{*}{$1-15$} \\
\hline Mass & 1.11 & $0.65-1.72$ & & \\
\hline \multicolumn{5}{|c|}{ Montastrea cavernosa } \\
\hline Linear & 4.36 & $3.3-6.8$ & \multirow[t]{2}{*}{14} & \multirow[t]{2}{*}{$4-28$} \\
\hline Mass & 0.70 & $0.53-1.09$ & & \\
\hline \multicolumn{5}{|c|}{ Porites astreoides } \\
\hline Linear & 4.75 & $2.9-6.9$ & \multirow[t]{2}{*}{20} & \multirow[t]{2}{*}{$1-15$} \\
\hline Mass & 0.70 & $0.43-1.02$ & & \\
\hline
\end{tabular}

combined with those of Weber and White (1977) (Fig. 2 ), there is an inverse correlation between growth rates and depth $\left(\mathrm{P}<.05, \mathrm{r}_{\mathrm{s}}=-.35, \mathrm{~N}=30\right.$; Spearman rank test). Also, the highest growth rates for all 3 species tended to occur in colonies living at less than $10 \mathrm{~m}$ depth (Fig. 2). The lack of an inverse correlation



Fig. 2. Mean annual linear coral growth rates relative to water depth. Data from Weber and White (1977)

between growth rate and water depth in $M$. annularis (our data only) and $P$. astreoides is a result of low growth rates for some of the shallow-water heads, probably reflecting locally unfavorable environmental conditions (Kissling, 1977; Highsmith, 1979) that override the light intensity-growth rate relationship (Goreau and Goreau, 1959; Goreau, 1963).

\section{Bioerosion: extent, location, agents}

Montastrea annularis was significantly more excavated by boring organisms (Table 2, Row 1) than $M$. cavernosa $(\mathrm{P}=.02)$ or Porites astreoides $(\mathrm{P}<.03$; Mann-Whtiney U-tests; although standard deviations are shown, non-parametric tests were used because percentages are not normally distributed).

The pyrgomatine barnacle Ceratoconcha domingensis (Des Moulins) 1867 commonly settles on Porites astreoides ( $\overline{\mathrm{x}}=7.4$ head $^{-1}, \mathrm{~N}=16$ heads $)$ and is embedded by subsequent growth of the coral, resulting in skeletal voids. Barnacles of this type were not found in either Montastrea species. Since these barnacles are not burrowers and their position in the upper, live portion of the coral posed little threat to the coral's attachment to the substratum, skeletal voids resulting from their presence are not included in Table 2, Row 1. Barnacle-caused voids made up $20.3 \%$ ( $\mathrm{sd}=27.0$, range $=0.0$ to 79.7 ) of all voids in $P$. astreoides and if included in bioerosional measurements, total slab excavation is increased to $6.3 \%(\mathrm{sd}=5.2$, range $=0.6$ 
Table 2. Montastrea annularis, $M$. cavernosa, Porites astreoides. Mean percentage of total skeletal slab area excavated, percentage of excavation by different borers, and various skeletal measurements. Excavation percentages for $P$. astreiodes do not include voids due to pyrgomatine barnacles. $\mathrm{N}=$ number of coral heads; $\mathrm{sd}=$ standard deviation

\begin{tabular}{|c|c|c|c|c|c|c|c|c|c|}
\hline \multirow[t]{2}{*}{ Parameter } & \multicolumn{3}{|c|}{$\begin{array}{l}\text { Montastrea } \\
\text { annularis } \\
\mathrm{N}=19\end{array}$} & \multicolumn{3}{|c|}{$\begin{array}{l}\text { Montastrea } \\
\text { Cavernosa } \\
\mathrm{N}=23\end{array}$} & \multicolumn{3}{|c|}{$\begin{array}{l}\text { Porites } \\
\text { astreoides } \\
\mathrm{N}=23\end{array}$} \\
\hline & $\overrightarrow{\mathrm{x}}$ & sd & Range & $\overrightarrow{\mathrm{x}}$ & sd & Range & $\bar{x}$ & sd & Range \\
\hline $\begin{array}{l}\text { 1. Percent of slab area exca- } \\
\text { vated }\end{array}$ & 7.9 & 4.6 & $2.1-23.2$ & 5.3 & 4.6 & $0.0-16.5$ & 4.8 & 4.8 & $0.6-11.8$ \\
\hline $\begin{array}{l}\text { 2. Percent of total boring lo- } \\
\text { cated in 'dead area' }\end{array}$ & 87.8 & 10.6 & $69.0-100$ & 85.6 & 22.2 & $0.0-100$ & 82.1 & 23.6 & $0.0-100$ \\
\hline $\begin{array}{l}\text { 3. Percent of 'dead area' ex- } \\
\text { cavated }\end{array}$ & 15.3 & 7.9 & $5.6-40.5$ & 12.1 & 8.3 & $0.0-30.1$ & 8.0 & 7.2 & $0.0-24.2$ \\
\hline $\begin{array}{l}\text { 4. Percent of slab area in- } \\
\text { cluded in 'dead area' }\end{array}$ & 45.4 & 14.8 & $26.5-69.9$ & 36.2 & 10.5 & $16.4-53.8$ & 55.1 & 14.3 & $32.5-81.7$ \\
\hline $\begin{array}{l}\text { 5. Percent of bored area due } \\
\text { to Porifera }\end{array}$ & 93.8 & 8.3 & $76.5-100$ & 87.0 & 23.2 & $0.0-100$ & 84.5 & 15.7 & $0.0-100$ \\
\hline $\begin{array}{l}\text { 6. Percent of bored area due } \\
\text { to Polychaeta }\end{array}$ & 1.7 & 3.4 & $0.0-8.6$ & 2.6 & 4.5 & $0.0-15.8$ & 15.7 & 15.9 & $0.0-58.0$ \\
\hline $\begin{array}{l}\text { 7. Percent of bored area due } \\
\text { to Bivalvia }\end{array}$ & 2.2 & 6.6 & $0.0-22.6$ & 3.3 & 11.1 & $0.0-48.7$ & 0.0 & - & - \\
\hline $\begin{array}{l}\text { 8. Percent of bored area due } \\
\text { to Sipuncula }\end{array}$ & 0.6 & 1.2 & $0.0-4.1$ & 0.3 & 1.3 & $0.0-6.0$ & 0.4 & 1.5 & $0.0-7.1$ \\
\hline $\begin{array}{l}\text { 9. Percent of bored area due } \\
\text { to unidentified organisms }\end{array}$ & 1.7 & 5.0 & $0.0-18.0$ & 2.4 & 6.2 & $0.0-25.0$ & 0.0 & - & - \\
\hline $\begin{array}{l}\text { 10. Ratio of circumference of } \\
\text { the basal attachment to the } \\
\text { circumference of the live } \\
\text { coral tissue margin }\end{array}$ & 0.46 & - & $0.24-0.71$ & 0.43 & - & $0.02-0.85$ & 0.37 & - & $0.09-0.68$ \\
\hline $\begin{array}{l}\text { 11. Ratio of circumference of } \\
\text { the basal attachment to } \\
\text { maximumcircumference of } \\
\text { the live portion of coral }\end{array}$ & 0.46 & - & $0.20-0.74$ & 0.42 & - & $0.02-0.85$ & 0.36 & - & $0.11-0.63$ \\
\hline $\begin{array}{l}\text { heads } \\
\text { 12. Volume (l) of intact coral }\end{array}$ & 0.89 & - & $0.4-2.1$ & 1.14 & - & $0.2-2.1$ & 0.83 & - & $0.2-2.8$ \\
\hline $\begin{array}{l}\text { heads } \\
\text { 13. Skeletal bulk density } \\
\left(\mathrm{g} \mathrm{cm}^{-3}\right) \text {. N and no. mea- } \\
\text { surements in parentheses }\end{array}$ & $1.75^{\circ}$ & & & $1.60(5,75)$ & & $1.19-2.0$ & $1.48(4,60)$ & & $1.26-1.68$ \\
\hline - Dustan (1975), $N=26$ & & & & & & & & & \\
\hline
\end{tabular}

to 18.7$)$. In this case, $M$. annularis was not significantly more excavated than $P$. astreoides $(\mathrm{P}<0.11)$. There was no difference in skeletal excavation between $P$. astreoides and $M$. cavernosa whether barnacle voids are included $(\mathrm{P}=0.12)$ or not $(\mathrm{P}=.47, \mathrm{z}=.08$; MannWhitney U-tests).

In all 3 species, most bioerosion occurred within $2 \mathrm{~cm}$ of a dead surface area, accounting for over $80 \%$ of total excavation (Table 2, Row 2). Within this area, Montastrea annularis was more bored than $M$. cavernosa, at the $\mathrm{P}=.065$ level, and Porites astreoides $(\mathrm{P}<.002$; Table 2 , Row 3). The 'dead area' in $M$. cavernosa was also more bored than that in $P$. astreoides $(\mathrm{P}=.03$; Mann-Whitney U-tests).

Boring sponges (Table 3) were the most important bioeroders in all cases (Table 2, Row 5; Fig. 3). They accounted for $93.8 \%$ of total boring in Montastrea annularis, $87.0 \%$ in $M$. Cavernosa and when barnacle voids are not included, for $84.5 \%$ of boring in Porites astreoides. The remaining borers in $M$. annularis and $M$. cavernosa in order of importance were: polychaetes, bivalves, unidentified burrowers and sipunculans (Table 2, Rows 6, 7, 8, 9). These groups each accounted for less than $4 \%$ of excavation. $P$. astreoides was not bored by bivalves, but mean polychaete damage $(15.7 \%)$ was greater than in either Montastrea species.

The ratio of the basal attachment circumference to the circumference of the live tissue margin was used by Highsmith $(1980,1981$ a) as an index of the relative amount of basal surface area exposed to settlement by borers, i.e. not protected by live coral tissue; the lower the ratio, the larger the exposed area. We found just the opposite relationship between the base/live ratio 
and skeletal excavation (Table 2, Rows 1, 10); Montastrea annularis had the highest ratio and was most eroded, whereas Porites astreoides had the lowest ratio but was least excavated. There are 2 major reasons for this difference from Highsmith's $(1980,1981$ a) data. First, a number of the $M$. annularis colonies had a columnar growth form (Fig. 3) with live tissue confined to the top of the column, rather than an approximately spherical shape for which the index was developed. This results in a relatively high base/live ratio that

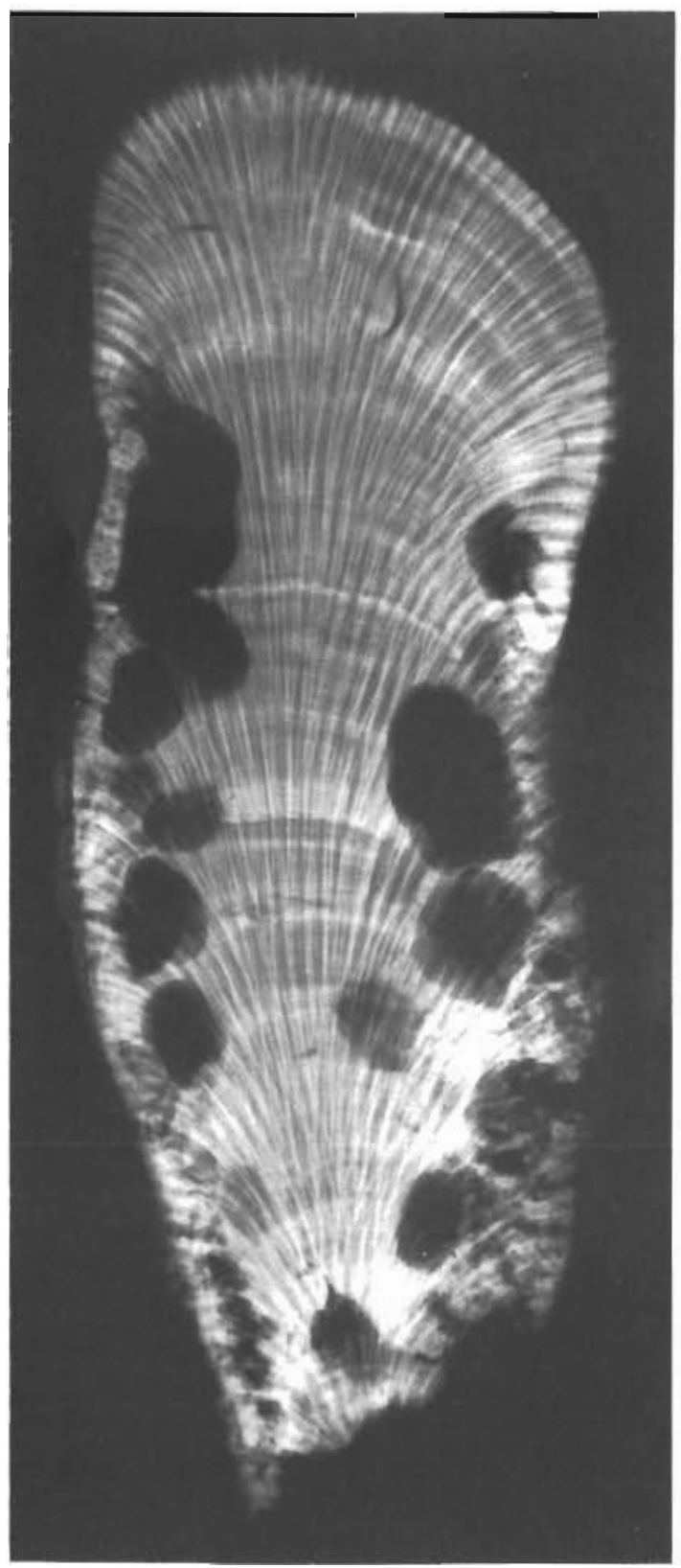

Fig. 3. Montastrea annularis. X-radiograph of slab illustrating sponge damage and columnar growth form. The large cavities were excavated by Siphonodictyon sp., the small peripheral cavities by Cliona sp. Slab is $22 \mathrm{~cm}$ in height substantially underestimates the surface area not covered by coral tissue. Secondly, the sponge Mycale laevis (Carter) often occurred on the underside of $P$. astreoides heads (Fig. 4). These heads tended to have a

Table 3. Boring sponges collected from selected massive corals at Carrie Bow Cay, Belize. For profile of reef zones, see Highsmith et al., 1980. Locations: 1, fore-reef slope; 2, outer ridge; 3 , inner reef slope; 4 , upper spur and groove zone; 5 , reef crest; 6 , patch reef zone; $7,10-\mathrm{km}$ patch reef. Sponges were identified by Dr K. Ruitzler

\begin{tabular}{|c|c|c|c|}
\hline Species & $\begin{array}{l}\text { Coral infested } \\
\text { (Ref. No.) }\end{array}$ & $\begin{array}{c}\text { Reef } \\
\text { location }\end{array}$ & $\begin{array}{l}\text { Depth } \\
\text { (m) }\end{array}$ \\
\hline \multirow[t]{4}{*}{$\begin{array}{l}\text { Cliona albicans } \\
\text { cf. Volz }\end{array}$} & $\begin{array}{l}\text { Montastrea } \\
\text { annularis (25) }\end{array}$ & 3 & 13 \\
\hline & $\begin{array}{l}\text { Montastrea } \\
\text { annularis (34) }\end{array}$ & 7 & 2 \\
\hline & M. cavernosa (12) & 4 & 11.5 \\
\hline & $\begin{array}{l}\text { Porites astreoides } \\
\text { (10) }\end{array}$ & 4 & 7.5 \\
\hline $\begin{array}{l}\text { Cliona caribbaea } \\
\text { Carter }\end{array}$ & M. annularis (34) & 7 & 2 \\
\hline \multirow[t]{3}{*}{ C. ensifera (Sollas) } & M. cavernosa (7) & 1 & 24.5 \\
\hline & M. cavernosa (8) & 1 & 21.5 \\
\hline & M. annularis (29) & 7 & 2 \\
\hline \multirow[t]{2}{*}{ C. laticavicola Pang } & M. annularis (23) & 3 & 13 \\
\hline & P. astreoides (35) & 4 & 6.5 \\
\hline C. peponaca Pang & M. cavernosa (18) & 1 & 24.5 \\
\hline C. topsenti & M. annularis (23) & 3 & 13 \\
\hline \multirow[t]{2}{*}{ Lendenfeld } & M. annularis (25) & 7 & 2 \\
\hline & P. astreoides (35) & 4 & 1.0 \\
\hline C. vermifera & M. cavernosa (5) & 1 & 27.5 \\
\hline Hancock & M. annularis (37) & 4 & 6.5 \\
\hline \multirow[t]{8}{*}{ Siphonodictyon sp. } & M. cavernosa (2) & 2 & 23.5 \\
\hline & M. cavernosa (18) & 1 & 24.5 \\
\hline & $M$. annularis (22) & 3 & 15.5 \\
\hline & M. annularis (37) & 4 & 6.5 \\
\hline & $M$. annularis (50) & 6 & 1.5 \\
\hline & P. astreoides (30) & 7 & 2 \\
\hline & P. astreoides (35) & 4 & 6.5 \\
\hline & P. astreoides (41) & 5 & 1 \\
\hline \multirow[t]{2}{*}{ Thoosa sp. } & M. annularis (9) & 2 & 15.5 \\
\hline & M. cavernosa $(21)$ & 3 & 24.5 \\
\hline
\end{tabular}

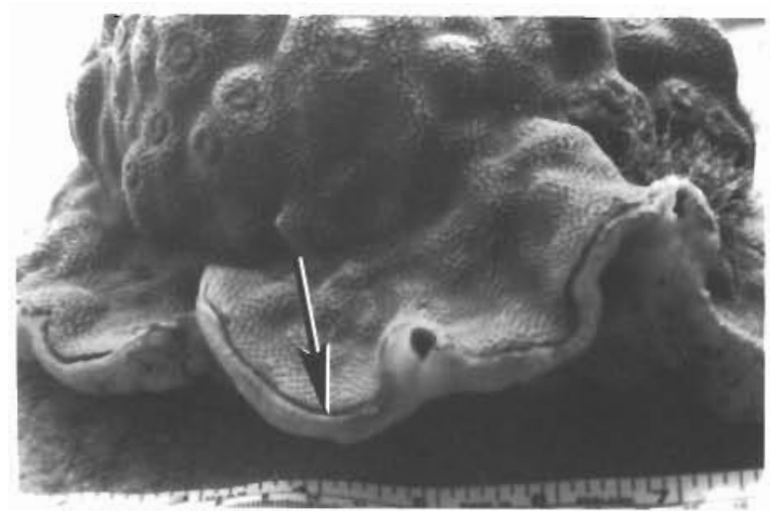

Fig. 4. Porites astreoides. Colony showing formation of a 'lip' around the margin, possibly due to the presence of the sponge Mycale laevis (arrow) 
well-developed skeletal 'lip', possibly induced by the sponge (Goreau and Hartman, 1966), at the edge of their live tissue, resulting in an exaggerated tissue margin circumference relative to the attachment circumference. At the same time, the sponge covers much of the basal surface, protecting it from colonization by boring organisms (Goreau and Hartman, 1966). Therefore, substantial departures in growth form from an ideally spherical shape resulted in overly high and low base/live ratios for $M$. annularis and $P$. astreoides, respectively.

The ratio of the attachment circumference to the maximum girth of massive coral heads (Table 2, Row 11) can be used as an index of how securely the corals are attached to the substratum (Highsmith, 1980, 1981a). These ratios range between 0 and 1 ; a low ratio indicates weak attachment. Because of the growth forms of these corals (see above), the base/maximum ratio for Montastrea annularis was significantly greater than that for Porites astreoides $(\mathrm{P}<.05)$ but not $M$. cavernosa; nor was the ratio for the latter greater than that for $P$. astreoides (Mann-Whitney U-tests).

Finally, our results were equivocal on the extent of skeletal excavation relative to colony size (Table 2 , Rows 1, 12) or water depth. Highsmith (1981a) found an inverse correlation between colony size and percent skeletal excavation for three massive coral species at Enewetak, suggesting that small colonies are more susceptible to bioerosional damage and that massive corals have a potential escape in size from severe weakening. Small Montastrea cavernosa colonies were more bioeroded than large colonies at the $.05<\mathrm{P}<.10$ level $\left(r_{s}=.33\right)$ but colony size and skeletal excavation were not correlated in M. annularis $\left(\mathrm{r}_{\mathrm{s}}=.03\right)$ or Porites astreoides $\left(r_{s}=-.01\right.$; Spearman rank tests).

With regard to a depth gradient, our results were also mixed on whether there is (Goreau and Hartman, 1963; MacGeachy and Stearn, 1976) or is not (High- smith, 1981a) a relationship between water depth and bioerosional damage to corals. In Montastrea cavernosa, skeletal excavation was not correlated with depth $\left(P \gg .05, r_{s}=.19, N=23\right)$ but percentage excavation tended to increase somewhat with greater depth in $M$. annularis $\left(\mathrm{r}_{\mathrm{s}}=.36, \mathrm{~N}=20\right)$ and Porites astreoides $\left(r_{s}=.33, N=23\right)(.05<P<.10$ in both cases: Spearman rank rests). In addition to the high rejection level for the latter 2 species, only 2 of the 23 p. astreoides were from depths greater than $10 \mathrm{~m}$, and 6 of the 10 most bioeroded heads occurred in less than $2 \mathrm{~m}$ of water. If there is a correlation between water depth and bioerosion, it is a very weak one.

\section{Bioerosion: effect on skeletal strength}

The reduction in coral skeletal strength due to the activities of burrowing organisms can be estimated by treating skeletal excavation as an increase in porosity (Highsmith, 1981a). The formula for the breaking strength of a material containing voids is $\sigma=\sigma_{0} e^{-n v}$ (Ryskewitch, 1953), where $\sigma_{0}$ is the strength of the material without pores, $\mathrm{n}$ is a constant between 4 and 7 , and $\mathrm{v}$ is the porosity. Non-porous aragonitic $\mathrm{CaCO}_{3}$ has a breaking strength of about $200 \mathrm{MNm}^{-2}$ (Currey and Kohn, 1976; Wainwright et al., 1976; Chamberlain, 1978) and the constant used in our calculations, found empirically for 3 heads with $40 \%$ porosity (Wainwright et al., 1976), was 5. The porosity of unbored corals was derived from measurements of their skeletal bulk density (Table 2, Row 13). The percent of excavation in the 'dead area' of corals (Table 2, Row 3) was used to estimate the increased porosity of corals bored in the region of the basal attachment (Highsmith, 1981a). The least porous of the 3 coral species, Montastrea annularis, had the highest initial strength, and vice versa (Table 4). However, when porosity was adjusted

Table 4. Estimates of coral strengths and effects of bioerosion and relative base size on strengths. Increase in porosity due to bioerosion is based on excavation in 'dead area' of heads (Table 2, Row 3). Base adjustment is derived from Table 2 , Row 11

\begin{tabular}{|c|c|c|c|c|c|}
\hline Coral & Mean density & $\begin{array}{c}\text { Mean porosity } \\
(\%)\end{array}$ & $\begin{array}{l}\text { Estimated } \\
\text { strength } \\
\left(\mathrm{MNm}^{-2}\right)\end{array}$ & $\begin{array}{c}\% \text { Weakened } \\
\text { by boring }\end{array}$ & $\begin{array}{c}\text { Estimated } \\
\text { strength } \\
\left(\mathrm{MNm}^{-2}\right) \text { after } \\
\text { base adjustment }\end{array}$ \\
\hline $\begin{array}{l}\text { Montastrea annularis } \\
\text { unbored } \\
\text { bored }\end{array}$ & 1.75 & $\begin{array}{l}40.5 \\
55.8\end{array}$ & $\begin{array}{l}26.4 \\
12.3\end{array}$ & 53 & $\begin{array}{l}26.4 \\
12.3\end{array}$ \\
\hline $\begin{array}{l}\text { Montastrea cavernosa } \\
\text { unbored } \\
\text { bored }\end{array}$ & 1.60 & $\begin{array}{l}45.6 \\
57.7\end{array}$ & $\begin{array}{l}20.5 \\
11.2\end{array}$ & 45 & $\begin{array}{r}17.0 \\
9.3\end{array}$ \\
\hline $\begin{array}{l}\text { Porites astreoides } \\
\text { unbored } \\
\text { bored }\end{array}$ & 1.48 & $\begin{array}{l}49.7 \\
57.7\end{array}$ & $\begin{array}{l}16.7 \\
11.2\end{array}$ & 33 & $\begin{array}{r}10.2 \\
6.8\end{array}$ \\
\hline
\end{tabular}


to reflect differences in bioerosional damage (Table 2 , Row 3), all 3 corals had approximately the same estimated skeletal strength. Strengths can also be adjusted according to differences in the size of the basal attachment relative to a given maximum circumference. The mean relative basal circumferences of $M$. cavernosa and Porites astreoides were 91 and $78 \%$ that of $M$. annularis (Table 2, Row 11) giving areas of attachment, 83 and $61 \%$ that of $M$. annularis. This adjustment results in the same rank order of strengths as found for differences in porosity (Table 4).

The actual reduction in skeletal strength due to bioerosion is probably greater than that resulting from an equivalent increase in porosity because bioerosional damage is concentrated in the basal 'dead area' and the bore holes probably have effects more similar to cracks which reduce breaking strength much more than increased porosity (Highsmith, 1981a). Thus, the greater the extent of skeletal excavation for a species, the larger may be the underestimation of skeletal weakening. The magnitude of this source of error is presently unknown but conceivably could reverse the rank order of unbored skeletal strengths.

\section{DISCUSSION}

\section{Growth rates}

Gladfelter et al. (1978) summarized growth rates for Montastrea annularis at various western Atlantic locations. Excluding the data of Lewis et al. (1968) for transplanted fragments and also data for flat colonies from deep water, growth rates were relatively consistent regardless of temperature, reef zone, or geographical area. In addition, Weber and White (1977) found mean growth rates ranging from $4.6 \mathrm{~mm} \mathrm{yr}^{-1}$ to $5.0 \mathrm{~mm}$ $\mathrm{yI}^{-1}$ for shallow-water specimens from Florida (Key West), Jamaica, and Panama. In Belize, Weber and White (1977) established a mean growth rate of $7.1 \mathrm{~mm}$ $\mathrm{yr}^{-1}$ (range 3.7 to $10.7, \mathrm{~N}=9$ ) for $M$. annularis collected at $0 \mathrm{~m}$ depth, and a mean rate of $4.1 \mathrm{~mm} \mathrm{yr}^{-1}$ (range 3.3 to $4.8, N=2$ ) for heads at 14 to $18 \mathrm{~m}$ depth; the mean for all depths was $6.55 \mathrm{~mm} \mathrm{yr}^{-1}$. We found a

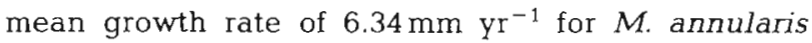
(Table 1). Although lower than rates for many other locations, this rate is within the range of 4.6 to $10.7 \mathrm{~mm}$ $\mathrm{yr}^{-1}$ average growth found by other workers (Weber and White, 1977; Gladfelter et al., 1978). The Carrie Bow reef, located approximately $20 \mathrm{~km}$ from the Belize coast (Ruitzler and Macintyre, 1982), is affected by runoff of cool, sediment-laden freshwater following storms. Sediment both reduces water clarity and requires an increased expenditure of energy by corals for cleaning activity, resulting in lower growth rates
(Dodge et al., 1974, Bak, 1978; Lasker, 1980). Also, hurricanes encounter the Belize barrier reef an average of once every 10 yr and may reduce growth rates directly by damaging coral tissues (Stoddart, 1963; Highsmith et al., 1980).

For Montastrea cavernosa, Weber and White (1977) reported an average growth rate of $3.4 \mathrm{~mm} \mathrm{yr}^{-1}$ (range 2.9 to $5.0, \mathrm{~N}=4$ ) for heads collected from 0 to $18 \mathrm{~m}$ depth at Belize. Although we found a slightly higher growth rate of $4.36 \mathrm{~mm} \mathrm{yr}^{-1}$ (Table 1), the 2 studies show that $M$. cavernosa grows more slowly both linearly and in mass deposition than $M$. annularis.

Using short-term staining techniques, Gladfelter et al. (1978) report Porites astreoides growth rates to be 3.0 to $3.5 \mathrm{~mm} \mathrm{yr}^{-1}$ in the backreef zone at St. Croix. These rates are considerably lower than the $4.75 \mathrm{~mm}$ $\mathrm{yr}^{-1}$ growth rate we found at Belize (Table 1) and somewhat lower than $x$-radiographically determined rates of $4.3 \mathrm{~mm} \mathrm{yr}^{-1}$ (fore reef) and $4.0 \mathrm{~mm} \mathrm{yr}^{-1}$ (reef flat) for Florida $P$. astreoides (Kissling, 1977). In addition to possible environmental differences between these habitats and locations, the low rates at St. Croix could be due also to the time of year or even particular year that the corals were stained.

\section{Growth rates vs water depth}

In spite of the positive relationship between light availability and calcification rate (Goreau and Goreau, 1959; Pearse and Muscatine, 1971; Chalker and Taylor, 1975; Chalker, 1977; Schmitz and Kremer, 1977), a decrease in linear growth rate with increasing water depth has been demonstrated for only a few coral species. In the Pacific Ocean, Buddemeier et al. (1974) reported growth rates for Porites Iutea at Enewetak decreased over a depth range of 4 to $30 \mathrm{~m}$. Highsmith (1979), also working at Enewetak, found an inverse correlation between growth rate and depth for $P$. lutea, Favia pallida, and Goniastrea retiformis.

In the Caribbean Sea, Bak (1976) found that growth in mass for Meandrina meandrites at Curacao decreased with depth but, conversely, that Agaricia agaricites mass increased more rapidly at $24 \mathrm{~m}$ than at $13 \mathrm{~m}$. At Jamaica, Dustan (1975) reported lower upward linear growth rates with increasing depth for Montastrea annularis. However, the growth form also changed from round to flat over the depth gradient studied and there was no significant relationship between depth and linear growth when growth was measured in the direction of polyp addition on the flat $M$. annularis colonies. All but 3 of the heads in Dustan's (1975) study were collected between depths of 15 and $45 \mathrm{~m}$, so additional data from shallower water could conceivably alter the latter finding. At St. Croix, 
Baker (1975) also found a decline in $M$. annularis growth rates over a depth span of 0 to $27 \mathrm{~m}$ but, again, flat growth forms occurred from 18 to $27 \mathrm{~m}$, the portion of the depth range in which lower growth rates were found. The distribution of $M$. annularis growth rates for Belize (Fig. 2) suggests that a relationship between growth rate and water depth might exist if we had a larger sample size or samples from depths greater than $15 \mathrm{~m}$. However, this depth represents the approximate lower limit of the massive growth form of this species at our study site. In order to increase the sample size, we combined our data with those of Weber and White (1977) for Belize M. annularis (Fig. 2). Analysis of the combined data (see results section) indicates that, though highly variable, $M$. annularis growth rates do tend to decrease at greater depths.

\section{Bioerosion}

Skeletal excavation in the 3 Belize coral species (Table 2, Row 1), when compared to results of other studies using similar methods, is less than that reported for corals from Barbados and Florida, and somewhat greater than in corals from Curacao and Enewetak. Mean skeletal excavation for 6 coral species ( 8 specimens) at Florida was $28 \%$ (Hein and Risk, 1975). At Barbados, MacGeachy and Stearn (1976) found mean excavation of $15 \%$ for 36 Montastrea annularis heads, and MacGeachy (1977) reported mean excavation due to sponge only of $8.6 \%$ for 45 heads of $M$. annularis. MacGeachy (1977) also found means of $5.9 \%$ and $5.2 \%$ for sponge excavation in 33 Siderastrea sp. and 39 Porites astreoides, respectively. Using slightly different methods, Bak (1976) reported an average of $1.4 \%$ excavation for $10 \mathrm{M}$. annularis and $1.7 \%$ for 5 Meandrina meandrites at Curacao. At Enewetak, Highsmith (1981a) found mean values of $7.8 \%$ for 18 Goniastrea retiformis, $2.5 \%$ for 56 Porites lutea, and $1.2 \%$ for 19 Favia pallida. Highsmith (1981a) also reported that the species with the highest percentage 'dead area' was, as predicted, the most extensively bored. We find a similar relationship for the 2 Montastrea species (Table 2, Row 4) but $P$. astreoides, the least excavated species, has the highest percent dead area. The dead basal region of the latter, however, is apparently enlarged and yet protected by the presence of the encrusting sponge Mycale laevis (Fig. 4).

In all 3 Belize coral species, over $80 \%$ of the boring was done by sponges (Table 2, Row 5). This level of infestation is similar to the range of 75 to $83 \%$ for sponge boring found by Highsmith (1981a) at Enewetak. Bak (1976) and MacGeachy and Stearn (1976) attribute over $90 \%$ of excavation to boring sponges. Sponges account for the majority of skeletal excavation, not only because they are the most common boring organisms in coral heads, but because a single sponge recruit can potentially excavate networks of tunnels and chambers throughout the nonliving periphery of coral skeletons. In contrast, individual bivalves, polychaetes and sipunculans make relatively small, discrete boreholes (Highsmith, 1981a).

Polychaetes, bivalves and sipunculans accounted for small amounts of bioerosion (Table 2, Rows 6, 7, 8) except in Porites astreoides where polychaetes accounted for $15.7 \%$ of damage. These groups were only responsible for small percentages of skeletal excavation at Barbados (MacGeachy and Stearn, 1976), Curacao (Bak, 1976), and Enewetak (Highsmith, 1981a) also. In contrast, Hein and Risk (1975) found polychaete excavation was almost as great as sponge damage in Florida corals.

In spite of the problems pointed out in the results section, the base/live and base/maximum ratios (Table 2 . Rows 10,11$)$ are quite similar to the mean ratios of .42 and .38 , respectively, reported by Highsmith (1980) for 251 western Atlantic corals from 11 locations. Highsmith (1980) also found that western Atlantic ratios were significantly lower than ratios for Indo-Pacific corals. Our data, in addition to supporting Highsmith's (1980) findings, may also provide at least a partial reason for the low western Atlantic ratios. In the species studied, Porites astreoides has the lowest ratios (Table 2, Rows 10, 11; also, 111 of the 251 western Atlantic corals in Highsmith's study were $P$. astreoides with a mean base/live ratio of .36) which, as noted in the results section, may be due to the influence of the sponge Mycale laevis on the coral's growth form. This sponge occurs on a variety of western Atlantic corals and has also been reported to affect the growth form of flat Montastrea annularis colonies (Goreau and Hartman, 1966). To our knowledge, there is no equivalent coral associate in the Indo-Pacific that results in a similar alteration of growth form. It is our general observation that sponges and other encrusting organisms appear to be more prominent on the bases and undersides of western Atlantic corals than Indo-Pacific corals, possibly due to higher nutrient availability and plankton productivity (Highsmith, 1980). In addition to having a potentially important influence on coral shapes, the encrusters may in some cases prevent or reduce recruitment of boring organisms (MacGeachy, 1977).

The general lack of an inverse correlation between bioerosion and colony size in Belize corals, in contrast to Highsmith's (1981a) results at Enewetak, may be due to the large basal area available for recuritment of borers as indicated by the low base/live ratios (Table 2 , 
Row 10). At Enewetak, these values ranged from .61 for the most eroded coral to 78 for the least eroded (Highsmith, 1981a). Since bioerosion is basically a surface phenomenon (Highsmith, 1981a), Enewetak corals, by maintaining live tissue on their bases, not only reduce recruitment of boring organisms but also enlarge the base commensurate with overall growth and thus, have a potential escape in size from catastrophic bioerosion. Such may not be the case for many western Atlantic corals.

\section{Patterns of bioerosion}

Results from Enewetak (Highsmith, 1981a) and Belize (this study) indicate that approximately 2 to 5 times more excavation occurs in the 'dead area' than in the balance of coral skeletons. The percent of total boring located in the 'dead area' ranged from 65 to $95 \%$ for 3 Enewetak species and from 82 to $88 \%$ for the 3 Belize species (Table 2, Row 2). Thus, the amount of bioerosion in individual corals depends to a great extent on the relative proportion of skeletal surface not covered by live coral tissue.

Secondly, bioerosional damage is positively correlated with coral skeletal bulk density (Table 2, Rows 1, 13). This relationship has been found also for other corals (V. Tunnicliffe, pers. comm.; Highsmith, 1981b); possibly dense species offer borers greater protection from predators and/or exposure by scraping grazers or perhaps coral species with dense skeletons may be less adept at keeping tissue over their skeleton (Highsmith, $1981 \mathrm{~b})$.

Finally, environmental differences due to geographic locations may contribute to overall patterns of bioerosion. Highsmith (1980) found that, on a gobal scale, bioerosional damage was correlated with geographic patterns of plankton primary productivity. The reason for this correlation is that at least 2 major boring organisms, bivalves and sponges, are planktivores. Skeletal damage in the Belize corals, though somewhat less than in corals at Florida or Barbados (where Amazon River discharge enhances nutrient availability; Kidd and Sander, 1979), is higher than that at Enewetak, in agreement with Highsmith's (1980) finding that bioerosion in western Atlantic corals, where productivity is generally higher, tends to be greater than in Indo-West Pacific corals.

Highsmith (1980) further proposed that a similar correlation between plankton productivity and bioerosion should occur in local situations where there are productivity gradients or differences. This hypothesis is still largely untested. Glynn et al. (in prep.), working at several locations in the Galapagos Islands, found that boring bivalves tended to be more abundant in corals at sites affected by upwelling than in corals at less affected sites. Highsmith (in prep.) established that lithophagine bivalves living in the coral Porites lobata are 3 times more abundant in the upwellingenriched Gulf of Panama ( $\bar{x}=4220 / \mathrm{m}$ ) than in the adjacent but less productive Gulf of Chiriqui $(\bar{x}=$ $1350 / \mathrm{m}$ ) and that the bivalves grow approximately twice as fast in the former location.

The primary productivity of waters passing over reefs generally increases 2- to 5-fold (Highsmith,

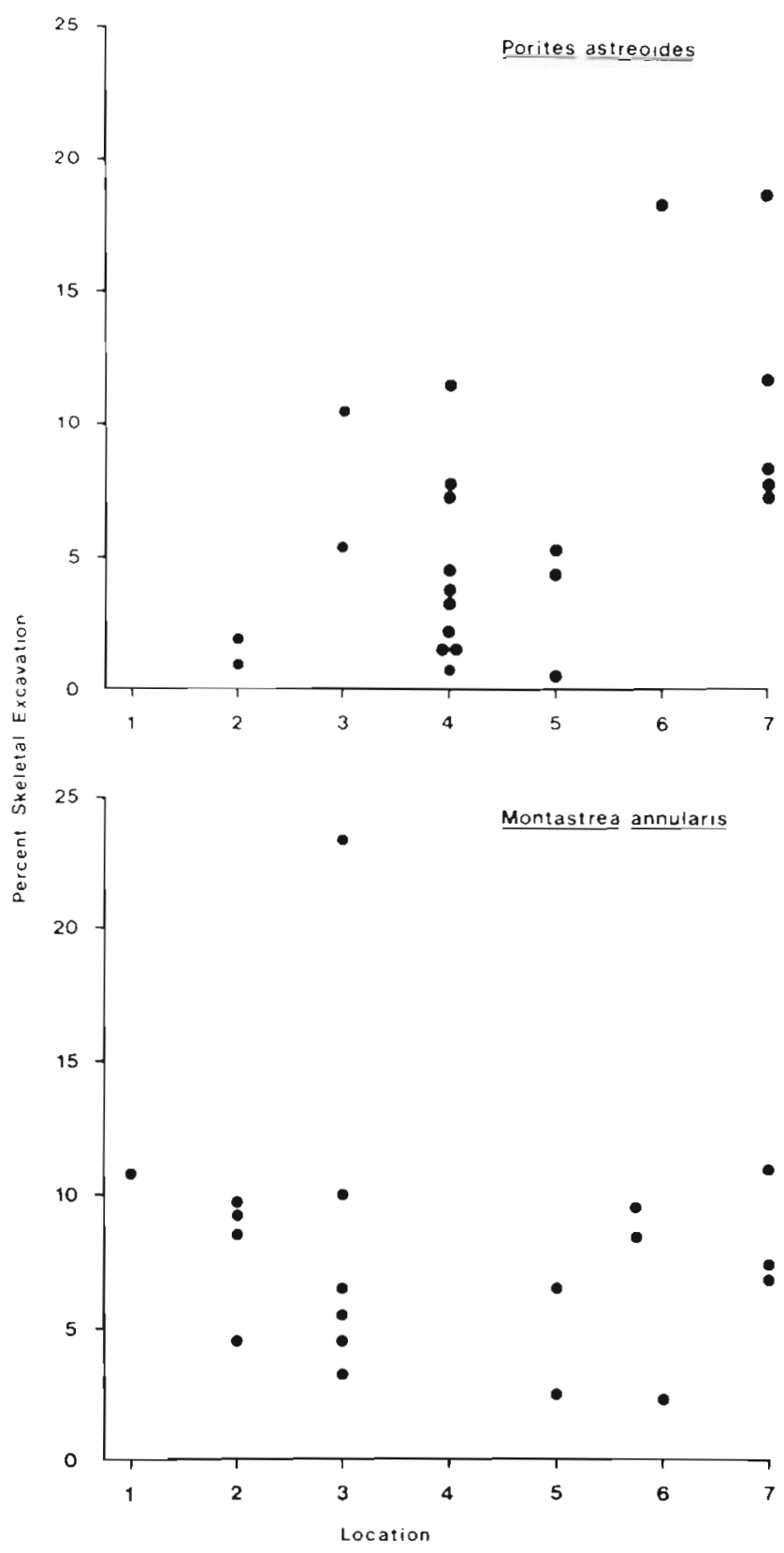

Fig. 5. Percent coral skeletal excavation relative to a probable gradient of increasing plankton primary productivity. 1 , forereef slope; 2 , inner reef slope; 3 , upper spur and groove zone; 4 , reef crest; 5 , patch reef zone; $6,3-\mathrm{km}$ patch reef; $7,10-\mathrm{km}$ patch reef 
1980). In addition, a number of workers have shown that productivity increases as a land or island mass is approached (e.g. Doty and Oguri, 1956; Sander and Steven, 1973; Hamner and Hauri, 1981). If the Belize collecting sites are arranged according to this presumed productivity gradient for the clear waters of the outer fore-reef to the green, low-visibility waters of the innermost lagoon patch reef (order given in Methods), percent skeletal excavation in Porites astreoides is positively correlated with plankton productivity $(\mathrm{P}<$ $.025, \mathrm{r}_{\mathrm{s}}=.48$; Fig. 5 ) but not in Montastrea annularis $\left(\mathrm{r}_{\mathrm{s}}\right.$ $=-.13$ ). The analysis for $M$. annularis is somewhat complicated by the fact that the first 2 collecting sites are also the deepest and, as indicated earlier, there is a weak correlation between depth and bioerosion in this species. A larger sampling program is needed to factor out the effects of depth, changes in growth form, and productivity. The data for $M$. cavernosa were not analyzed because 21 of the 23 heads were collected at just 3 of the sites. These very preliminary data, combined with those of the other studies mentioned above, tend to support the hypothesis that bioerosion is also correlated with local patterns of plankton primary productivity.

Acknowledgements. We thank Dr. K. Rützler for use of facilities at the Smithsonian's IMSWE Laboratory, Carrie Bow Cay, Belize, and Mr. H. Bowman, Jr. for local arrangements. We are also grateful to R. Larson, A. Riggs and P. Videtich for field assistance, to Drs. K. Rützler, W. Hartmann and W. Newman for identifying boring sponges, Mycale laevis, and Ceratoconcha domingensis, respectively, to Drs. P. W. Glynn, A. J. Kohn, H. Lessios and M. Yamaguchi for reading drafts of the manuscript, and to D. D. Highsmith for typing. Supported by the Smithsonian Institution, a University of Washington Annual Fund Predoctoral Award (to $\mathrm{RCH}$ ), the Smithsonian Tropical Research Institute (for support of RCH during ms preparation), and NSF grant OCE 76-21271. This is contribution No. 116 of the Investigations of Marine Shallow Water Ecosystems, Smithsonian Institution, partly supported by a grant from the Exxon Corporation.

\section{LITERATURE CITED}

Bak, R. P. M. (1976). The growth of coral colonies and the importance of crustose coralline algae and burrowing sponges in relation with carbonate accumulation. Neth. J. Sea Res. 10: 285-337

Bak, R. P. M. (1978). Lethal and sublethal effects of dredging on reef corals. Mar. Pollut. Bull. 9: 14-16

Baker, P. A. (1975). Coral growth rate: variation with depth. M. S. thesis, Pennsylvania State University, State College

Buddemeier, R. W., Maragos, J. E., Knutson, D. (1974). Radiographic studies of reef coral exoskeletons: rates and patterns of coral growth. J. exp. mar. Biol. Ecol. 14 $179-200$

Chalker, B. E. (1977). Daily variation in the calcification capacity of Acropora cervicornis. Proc. 3rd Int. Coral Reef Syrmp. 2: $417-423$
Chalker, B. E., Taylor, D. L. (1975). Light-enhanced calcification, and the role of oxidative phosphorylation in calcification of the coral Acropora cervicornis. Proc. R. Soc. (B) 190 : 323-331

Chamberlain, J. A., Jr. (1978). Mechanical properties of coral skeleton: compressive strength and its adaptive significance. Paleobiology 4: 419-435

Currey, J. D., Kohn, A. J. (1976). Fracture in the crossedlamellar structure of Conus shells. J. Mat. Sci. 11: $1615-1623$

Dodge, R. E. (1978). The natural growth records of reef building corals. Ph. D. thesis, Yale University, New Haven

Dodge, R. E., Aller, R. C., Thompson, J. (1974). Coral growth related to resuspension of bottom sediments. Nature, Lond. 247: $574-577$

Doty, M. S., Oguri, M. (1956). The island mass effect. J. Cons. perm. int. Explor. Mer 22: 33-37

Dustan, P. (1975): Growth and form in the reef-building coral Montastrea annularis. Mar. Biol. 33: 101-107

Gladfelter, E. H., Monahan, R. K., Gladfelter, W. B. (1978). Growth rates of five reef-building corals in the northeastern Caribbean. Bull. mar. Sci. 28: 728-734

Glynn, P. W. Wellington, G. M., Wells, J. W. (in prep.). Corals and coral reefs of the Galapagos Islands. University California Press, Berkeley

Goreau, T. F. (1959). The ecology of Jamaican coral reefs. I. Species composition and zonation. Ecology 40:67-90

Goreau, T. F. (1963). Calcium carbonate deposition by coralline algae and corals in relation to their roles as reef builders. Ann. N. Y. Acad. Sci. 109: 127-167

Goreau, T. F., Goreau, N. I. (1959). The physiology of skeleton formation in corals. II. Calciurn deposition by hermatypic corals under various conditions in the reef. Biol. Bull. mar. biol. Lab., Woods Hole 117: 239-250

Goreau, T. F., Hartman, W D. (1963). Boring sponges as controlling factors in the formation and maintenance of coral reefs. In: Sognnaes, R. F. (ed.) Mechanisms of hard tissue destruction. Publs Am. Ass. Advmt Sci. 75: 25-54

Goreau, T. F., Hartman, W. D. (1966). Sponge: effect on the form of reef corals. Science, N. Y. 151: 343-344

Hamner, W. M., Hauri, I. R. (1981). Effects of island mass: water flow and plankton pattern around a reef in the Great Barrier Reef lagoon, Australia. Limnol. Oceanogr. 26: 1084-1102

Hein, F. J., Risk, M. J. (1975). Bioerosion of coral heads: inner patch reefs, Florida reef tract. Bull. mar. Sci. 25: 133-138

Highsmith, R. C. (1979). Coral growth rates and environmental control of densitiy banding. J. exp. mar. Biol. Ecol. 37 : $105-125$

Highsmith, R. C. (1980). Geographic patterns of coral bioerosion: a productivity hypothesis. J. exp. mar. Biol. Ecol. 46: $177-196$

Highsmith, R. C. (1981a). Coral bioerosion at Enewetak: agents and dynamics. Int. Revue ges. Hydrobiol. 66: $335-375$

Highsmith, R. C. (1981b). Coral bioerosion: damage relative to skeletal density. Am. Nat. 117: 193-198

Highsmith, R. C., Riggs, A. C., D'Antonio, C. M. (1980). Survival of hurricane-generated coral fragments and a disturbance model of reef calcification/growth rates. Oecologia (Berl.) 46: 322-329

Hudson, J. H., Shinn, E. A., Halley, R. B., Lidz, B. (1976). Sclerochronology: a tool for interpreting past environments. Geology 4: 361-364

Kidd, R., Sander, F. (1979). Influence of Amazon River discharge on the marine production system off Barbados, Wiest Indies. J. mar Res. 37: 669-681 
Kissling, D. L. (1977). Population structure characteristics for some paleozoic and modern colonial corals. Mem. Bur. Rech. Geol. Minier. 89: 497-506

Knutson, D. W., Buddemeier, R. W., Smith, S. V. (1972). Coral chronometers: seasonal growth bands in reef corals. Science, N. Y. 177: 270-272

Lasker, H. R. (1980). Sediment rejection by reef corals: the roles of behavior and morphology in Montastrea cavernosa (Linnaeus). J. exp. mar. Biol. Ecol. 47: 77-87

Lewis, J. B. Axelson, F., Goodbody, I., Page, C., Chislett, G. (1968). Comparative growth rates of some corals in the Caribbean. Mar Sci. Manuscript Rep., McGill Univ. 10: $1-26$

McGeachy, J. K. (1977). Factors controlling sponge boring in Bãrbados reef corals. Proc. 3rd Int. Coral Reef Symp. 2: $477-483$

MacGeachy, J. K., Stearn, C. W. (1976). Boring by macroorganisms in the coral Montastrea annularis on Barbados reefs. Int. Revue ges. Hydrobiol. 61: 715-745

Pearse, V. B., Muscatine, L. (1971). Role of symbiotic algae (zooxanthellae) in coral calcification. Biol. Bull. mar. biol Lab., Woods Hole 141: 350-363

Ryskewitch, T. (1953). Compression strength of porous sintered alumina and zirconia. J. Am. Ceram. Soc. 36: 65-68

Rützler, K., Macintyre, I. (1982). The habitat distribution and community structure of the barrier reef complex at Carrie Bow Cay, Belize. In: Rützler, K., Macintyre, I. (ed.) The Atlantic barrier reef ecosystem at Carrie Bow Cay, Belize, I. Structure and communities. Smithsonian Press, Washington, D. C., p. 9-45

Sander, F., Steven, D. M. (1973). Organic productivity of inshore and offshore waters of Barbados: a study of the island mass effect. Bull. mar. Sci. 23: 771-792

Schmitz, K., Kremer, B. P. (1977). Carbon fixation and analysis of assimilates in a coral-dinoflallate symbiosis. Mar. Biol. 42: 305-313

Stoddart, D. R. (1963). Effects of Hurricane Hattie on the British Honduras reefs and cays, October 30-31, 1961. Atoll Res. Bull. 95: 1-142

Wainwright, S., Biggs, W., Currey, J., Gosline, J. (1976). Mechanical design in organisms. John Wiley and Sons, New York

Weber, J. N., White, E. W. (1977). Caribbean reef corals Montastrea annularis and Montastrea cavernosa - longterm growth data as determined by skeletal x-radiography. In: Frost, S. H., Weiss, M. P., Saunders, J. B. (ed.) Reefs and related carbonates - ecology and sedimentology. Am. Ass. Petrol, Geol., Tulsa, Oklahoma (Stud. Geol. Am. Ass. Petrol. Geol. No. 4: 171-179) 